\title{
Effects of atosiban on stress-related neuroendocrine factors
}

\author{
S Babic', M Pokusa', V Danevova, ${ }^{1,2}$, S T Ding ${ }^{3}$ and D Jezova' \\ ${ }^{1}$ Laboratory of Pharmacological Neuroendocrinology, Institute of Experimental Endocrinology, \\ Slovak Academy of Sciences, Vlarska 3, 83306 Bratislava, Slovakia \\ ${ }^{2}$ Department of Pharmacology and Toxicology, Faculty of Pharmacy, Comenius University, \\ Odbojarov 10, 83232 Bratislava, Slovakia \\ ${ }^{3}$ Biotechnology Center, National Taiwan University, 50, Lane 155, Keelong Road, \\ Section 3, Taipei, Taiwan
}

Correspondence
should be addressed
to D Jezova
Email
daniela.jezova@savba.sk

\begin{abstract}
Atosiban, an oxytocin/vasopressin receptor antagonist, is used to decrease preterm uterine activity. The risk of preterm delivery is undoubtedly associated with stress, but potential side effects of atosiban on neuroendocrine functions and stress-related pathways are mostly unknown. These studies were designed to test the hypothesis that the chronic treatment of rats with atosiban modulates neuroendocrine functions under stress conditions. Male rats were treated (osmotic minipumps) with atosiban (600 $\mu \mathrm{g} / \mathrm{kg}$ per day) or vehicle and were restrained for $120 \mathrm{~min} /$ day for 14 days. All animals were treated with a marker of cell proliferation 5-bromo-2-deoxyuridine. Anxiety-like behavior was measured using an elevated plus-maze. Treatment with atosiban failed to modify plasma concentrations of the stress hormones ACTH and corticosterone, but led to a rise in circulating copeptin. Atosiban increased prolactin levels in the non-stressed group. Oxytocin receptor mRNA levels were increased in rats exposed to stress. Treatment with atosiban, in both control and stressed animals, resulted in a decrease in oxytocin receptor gene expression in the hypothalamus. No changes were observed in vasopressin receptor $1 \mathrm{~A}$ and $1 \mathrm{~B}$ gene expression. The decrease in hippocampal cell proliferation induced by stress exposure was not modified by atosiban treatment. This study provides the first data, to our knowledge, revealing the effect of atosiban on gene expression of oxytocin receptors in the brain. Atosiban-induced enhancement of plasma copeptin indicates an elevation in vasopressinergic tone with potential influence on water-electrolyte balance.
\end{abstract}

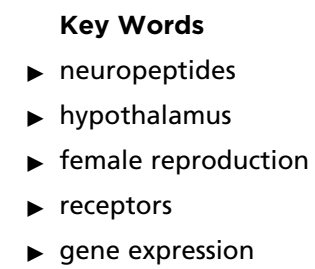

Journal of Endocrinology (2015) 225, 9-17

\section{Introduction}

Atosiban is a known antagonist of oxytocin and vasopressin receptors and is clinically used to decrease preterm uterine activity and preterm labor (Goodwin et al. 1994, Usta et al. 2011). Generally, atosiban is considered to be a relatively safe drug with a better adverse effect profile compared with other tocolytics (Husslein et al. 2006). However, the risk of preterm delivery is associated with many stressful situations and the knowledge of the effects of atosiban during stress conditions is limited.
The activation of release of anterior pituitary hormones, such as adrenocorticotropic hormone (ACTH) or prolactin, is one of the main characteristics of the stress response (Jezova \& Hlavacova 2008). Knowledge regarding the potential effects of atosiban on stress hormone release is very limited. Hormones of the posterior pituitary, oxytocin, and vasopressin, the receptors of which are blocked by atosiban, are also involved in the stress response. Under stress conditions, gene expression of

Published by Bioscientifica Ltd. 
oxytocin in the hypothalamus as well as the concentration of oxytocin in the peripheral circulation and in the brain is increased. Vasopressin is released particularly in response to stress stimuli with an osmotic component (Jezova et al. 1995, Neumann 2007, Babygirija et al. 2012).

Among the negative consequences of chronic stress exposure are changes in brain plasticity, with consequent development of psychopathologies and cognitive impairments (Duncko et al. 2001, Hemmerle et al. 2012, Izakova \& Jezova 2013). Stress-induced decreases in parameters of brain plasticity, such as glutamatergic neurotransmission, long-term potentiation, synaptogenesis, and adult neurogenesis, are under the influence of several regulatory factors including posterior pituitary neuropeptides (McEwen 2012).

Exposure to stressors, occurring under demanding life situations as well as under experimental conditions, induces neuroendocrine activation associated with increased anxiety (Jezova \& Hlavacova 2008). Oxytocin and vasopressin receptors have been implicated in the regulation of anxiety and stress responses (Mak et al. 2012, Bowen \& McGregor 2014). In contrast to the knowledge regarding the actions of atosiban on reproductive functions, the information available on its effects on the brain is very limited (Broadbear et al. 2014).

The main objective of the present studies was to test the hypothesis that the chronic treatment of rats with the oxytocin/vasopressin receptor antagonist atosiban modulates neuroendocrine functions under stress conditions, namely the gene expression of oxytocin and vasopressin receptors in the hypothalamus as well as circulating concentrations of ACTH, corticosterone, prolactin, oxytocin, and copeptin, a stable peptide of the vasopressin precursor. To avoid interference due to hormonal change during the estrous cycle (Bale et al. 1995), male rats were selected as experimental animals. In addition, cell proliferation in the hippocampus as a parameter of brain plasticity and anxiety behavior were measured.

\section{Materials and methods}

\section{Animals}

Seven-week-old male Wistar rats (AnLab s.r.o., Prague, Czech Republic) (150-175 g) were used in this study. Rats were allowed to acclimate to the housing facility for 7 days before testing. They were kept in temperature-controlled housing room $\left(22 \pm 2^{\circ} \mathrm{C}\right)$ under constant $12 \mathrm{~h}$ light: $12 \mathrm{~h}$ darkness cycle (lights on at $0600 \mathrm{~h}$ ). Animals were housed individually in standard cages with free access to rat chow and tap water. All experimental procedures were approved by the Animal Health and Animal Welfare Division of State Veterinary and Food Administration of the Slovak Republic and conformed to the NIH Guidelines for Care and Use of Laboratory Animals.

\section{Experimental procedures}

The animals were randomly assigned into two treatment groups ( $n=16$ rats/group), vehicle- and atosiban-treated rats. Atosiban (Sigma-Aldrich) or vehicle (saline) was continuously administered via osmotic minipumps (Model 2002, Alzet, Alza Corp., Mountain View, CA, USA) for 15 days. Osmotic minipumps were implanted subcutaneously as described previously (Hlavacova \& Jezova 2008). The concentration of atosiban used to fill the pumps was calculated based on the mean pump infusion rate provided by the manufacturer $(0.5 \mu \mathrm{l} / \mathrm{h}, 14$ days), the body weight of animals, and the dose intended. The minipumps delivered atosiban at a dose of $600 \mu \mathrm{g} / \mathrm{kg}$ body weight per day. This dose has been demonstrated to block oxytocin receptors on rat myometrium (Engstrøm et al. 2000). Control animals received minipumps that contained vehicle only. After implantation, rats were housed individually. As prolonged atosiban treatment might have an effect on water balance, the water consumption was measured daily.

Half of the animals from each treatment group were exposed daily to a stress paradigm. The second half remained undisturbed in their home cages. According to the treatment and stress exposure, rats were finally assigned to one of four experimental groups ( $n=8$ rats/group): i) CONTROL-VEHICLE, rats treated with vehicle without stress exposure; ii) CONTROL-ATOSIBAN, rats treated with atosiban without stress exposure; iii) STRESS-VEHICLE, rats treated with vehicle with stress exposure; and iv) STRESSATOSIBAN, rats treated with atosiban with stress exposure.

On the 13th day of the experiment, all animals were subjected to behavioral testing in the elevated plus maze to evaluate anxiety-like behavior. The testing was performed during the daytime when animals were most active starting at $1900 \mathrm{~h}$.

On the 14th day of the experiment, all animals were treated with 5-bromo-2-deoxyuridine (BrdU) (Roche), an indicator of cell proliferation. BrdU was injected twice at a dose of $100 \mathrm{mg} / \mathrm{kg}$ intraperitoneally. The administration was in the afternoon and the time interval between the first and second injections was $4 \mathrm{~h}$. Tissues were collected at approximately $17 \mathrm{~h}$ after the last BrdU injection.

Published by Bioscientifica Ltd. 
On the 15th day of the experiment, animals were not exposed to the stress paradigm, but both control and stressed animals were killed by decapitation (approximately $24 \mathrm{~h}$ after last stress exposure). The trunk blood was collected into cooled polyethylene tubes containing EDTA as an anticoagulant and centrifuged immediately at $4{ }^{\circ} \mathrm{C}$ to separate plasma, which was stored at $-20^{\circ} \mathrm{C}$ until analysis. The brain was quickly removed from the skull. The hippocampus and hypothalamus were dissected, frozen in liquid nitrogen, and stored at $-70{ }^{\circ} \mathrm{C}$ until analysis.

\section{Stress model}

Restraint stress was induced by taping all four limbs of the rat to metal mounts attached to a wooden board as described previously (Jezova et al. 1998). The immobilization was performed between 0830 and $1130 \mathrm{~h}$, lasted for $120 \mathrm{~min}$, and was repeated once daily for 14 days.

\section{Elevated plus maze test}

On the 13th day of experiment, animals were subjected to the elevated plus maze test for $5 \mathrm{~min}$. The maze was employed as described previously (Hlavacova \& Jezova 2008). Each rat was placed on the central platform of the maze facing an enclosed arm. The number of entries and time spent in the open arms were used as measures of the anxiety level. An arm entry was defined as all four paws entering the arm. Ethological measures included the frequency of stretched attend postures, of head dipping (exploratory movement in which the animal's head is protruding over the side of the open arm and down toward the floor), and of rearing. Stretched attend postures and head dipping were differentiated as protected (occurring in the closed arms or central platform) or unprotected (occurring in the open arms).

\section{Analysis of cell proliferation in the hippocampus}

The dissected hippocampus was sonicated using an MSE sonicator (Scientific Instruments, Darwen, England) with an intensity of $5 \mathrm{~mm}$ amplitude in Tris buffer $(50 \mathrm{mM} \mathrm{NaCl}$, $10 \mathrm{mM}$ Tris- $\mathrm{HCl}, \mathrm{pH} 7.5)$ for $20 \mathrm{~s}$. DNA was extracted from $20 \mathrm{mg}$ of sonicated tissue using a commercially available nucleic acid purification kit (Wizard genomic DNA Purification kit, Promega), according to the manufacturer's instructions. DNA concentrations were measured photometrically (GeneQuant Pro, Biochrom Ltd, Cambridge, UK) at a wavelength of $260 \mathrm{~nm}$ and stored at $4-7^{\circ} \mathrm{C}$. BrdU incorporation into DNA was measured by ELISA as described previously (Babic et al. 2012, Babic \& Jezova 2014).

\section{RNA isolation and real-time PCR analysis}

Total RNA from hypothalamus was isolated using an SV total RNA isolation system (Promega). Isolated RNA $(1 \mu \mathrm{g})$ was reverse transcribed using oligo(dT) nucleotides and the ImProm-II RT system (Promega). Real-time qPCR was used for quantitative evaluation of gene expression of oxytocin receptor and vasopressin receptor 1A. Analyses were performed in $20 \mu \mathrm{l}$ reaction volume using GoTaq qPCR Master Mix (Promega). ROX was used as a reference dye. Specific primers (Table 1) for oxytocin receptor (Devidze et al. 2005), vasopressin 1A, and vasopressin $1 \mathrm{~B}$ receptors were used at a concentration of $0.25 \mathrm{pmol} / \mu \mathrm{l}$. The reaction mixture consisted of $10 \mu \mathrm{l}$ GoTaq qPCR Master Mix, $0.2 \mu \mathrm{l}$ ROX (Promega), $1 \mu \mathrm{l}$ forward primer and $1 \mu \mathrm{l}$ reverse primer ( $5 \mu \mathrm{M}$ stock solution), and $5 \mathrm{ng}$ cDNA for analysis and water was added to make up the volume to $20 \mu \mathrm{l}$. qPCR was performed using a Fast Real-Time PCR System 7900 HT (Applied Biosystems). Initial denaturation at $95{ }^{\circ} \mathrm{C}$ for $10 \mathrm{~min}$ was followed by 40 cycles at $95^{\circ} \mathrm{C}$ for $15 \mathrm{~s}$ and $60{ }^{\circ} \mathrm{C}$ for $30 \mathrm{~s}$ and $72{ }^{\circ} \mathrm{C}$ for $30 \mathrm{~s}$. Melting curve analysis was performed for $20 \mathrm{~min}$ and did not detect any non-specific products of PCR. Gene expression levels were normalized to housekeeping gene ribosomal protein S29 (Table 1). The data obtained by real-time PCR were quantified by the $2^{-\Delta \Delta C t}$ method (Livak \& Schmittgen 2001).

Owing to the high homology of oxytocin and vasopressin, the TaqMan Gene Expression Assay num. Rn01515060_g1 (Applied Biosystems) was used for

Table 1 Specific primers used for gene expression measurements in Wistar rats. Primers used for gene expression measurements

Target gene
Oxr
Vp1a
Vp1b
Rps29

Forward primer $\mathbf{5}^{\prime} \mathbf{- 3}^{\prime}$
TTCTTCTGCTGCTCTGCTCGT
TCATTGTCCAGATGTGGTCAGTCT
TGGTCTGTGTGGGATGAGAATG
GCTGAACATGTGCCGACAGT

Reverse primer $\mathbf{5}^{\prime} \mathbf{- 3}^{\prime}$
TCATGCTGAAGATGGCTGAGA
CAACGCCGTGATTGTGATG
TGTTGAAGCCCATGTAGATCCA
GGTCGCTTAGTCCAACTTAATGAA

Oxr, oxytocin receptor; Vp1a, vasopressin 1A receptor; $V p 1 b$, vasopressin 1B receptor; $R p s 29$, ribosomal protein $\$ 29$.

http://joe.endocrinology-journals.org DOI: $10.1530 / \mathrm{JOE}-14-0560$
(C) 2015 Society for Endocrinology Printed in Great Britain
Published by Bioscientifica Ltd 
the measurement of oxytocin gene expression in the hypothalamus by real-time PCR. This assay permits amplification of mRNA responsible for the translation of oxytocin prepropeptide and it was performed according to the manufacturer's protocol.

\section{Hormone measurements}

Plasma concentrations of corticosterone were analyzed by RIA after dichloromethane extraction as described previously (Jezova et al. 1994). The intra- and inter-assay coefficient of variation $(\mathrm{CV})$ values were $6 \%$ and $8 \%$ respectively and the sensitivity of the assay was $0.5 \mu \mathrm{g} / 100 \mathrm{ml}$ plasma. Concentrations of oxytocin in plasma were measured using a commercially available EIA kit (Oxytocin EIA kit, Enzo Life Sciences, Farmingdale, NY, USA). The intra- and inter-assay CV values were $4.7 \%$ and $10 \%$ respectively and the sensitivity of the oxytocin kit was $11.7 \mathrm{pg} / \mathrm{ml}$. Concentrations of copeptin and prolactin in plasma were measured using commercially available ELISA kits (Rat Copeptin ELISA kit, Cusabio Biotech Co., Hubei, China; Prolactin rat ELISA, Demeditec Diagnostics, Kiel-Wellsee, Germany). The intra- and interassay CV values for the copeptin kit were $8 \%$ and $10 \%$ respectively and the sensitivity of the kit was $15.6 \mathrm{pg} / \mathrm{ml}$. The intra- and inter-assay CV values for the prolactin kit were $4.13 \%$ and $4.06 \%$ respectively and the sensitivity of the prolactin kit was $0.6 \mathrm{ng} / \mathrm{ml}$. Concentrations of ACTH in plasma were measured using a commercially available RIA kit (ACTH (rat, mouse) RIA kit, Phoenix Pharmaceuticals, Inc., Burlingame, CA, USA). The intra- and interassay $\mathrm{CV}$ values were $4.5 \%$ and $10 \%$ respectively and the sensitivity of the ACTH kit was $34.1 \mathrm{pg} / \mathrm{ml}$. All hormone measurements were performed in duplicate.

\section{Statistical analysis}

All data were analyzed using factorial two-way ANOVA with treatment and stress as main factors. Whenever interaction reached significance, the Fisher post hoc test was performed. Results are expressed as mean \pm s.E.M. The overall level of statistical significance was defined as $P<0.05$.

\section{Results}

Plasma concentrations of ACTH (Fig. 1A) and corticosterone (results not shown), the main hormones of the hypothalamic-pituitary adrenocortical axis, were unchanged $24 \mathrm{~h}$ after the last stress exposure in both treatment groups. Treatment with prolactin had a mild stimulatory effect on prolactin release. The statistical analysis by two-way ANOVA following exclusion of one outlier (Box-Plot analysis) revealed a marginal main effect of the treatment $(P=0.06)$. If the effect of atosiban was compared with the effect of vehicle in the control, unstressed group only, the effect of the treatment was statistically significant $(P<0.05$; Fig. 1B).

Oxytocin concentrations in plasma were higher in rats exposed to stress $\left(F_{(1,26)}=10.913, P<0.01\right)$ compared with the values in controls (Fig. 1C). Treatment with atosiban had no effect on oxytocin concentrations in plasma. Neither treatment with atosiban nor stress exposure altered the abundance of oxytocin mRNA in the hypothalamus (Fig. 2A). Gene expression of oxytocin receptor in the hypothalamus was affected by both stress exposure and atosiban treatment. Hypothalamic concentrations of mRNA coding for oxytocin receptor were significantly greater $\left(F_{(1,25)}=5.4498, P<0.05\right)$ in rats exposed to stress compared with those in control rats and were significantly less $\left(F_{(1,25)}=4.5721, P<0.05\right)$ in rats treated with atosiban compared with those treated with vehicle (Fig. $2 \mathrm{~B}$ ).

Plasma concentrations of copeptin increased in response to atosiban treatment but not in response to stress exposure. Plasma copeptin $\left(F_{(1,25)}=6.6657, P<0.05\right)$ was significantly higher in animals treated with atosiban (Fig. 1D). Gene expression of vasopressin 1A (Fig. 2C) and 1B receptors (Fig. 2D) in the hypothalamus was not
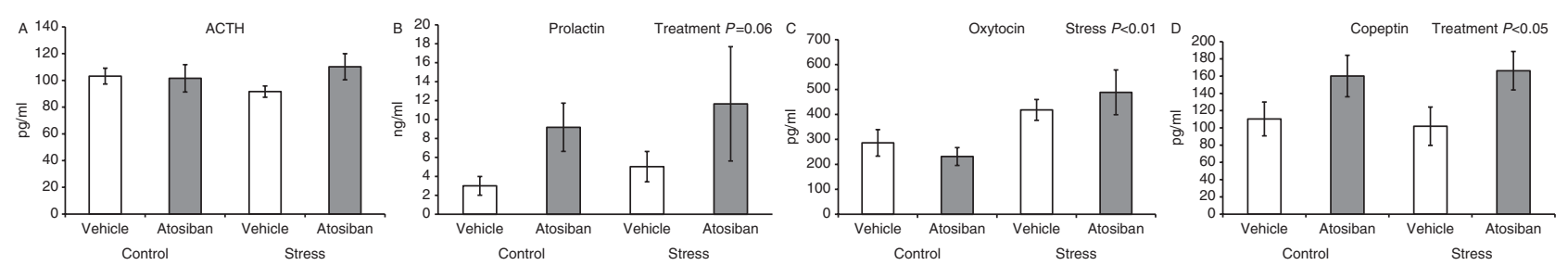

Figure 1

Effect of atosiban treatment and chronic stress exposure on plasma concentrations of ACTH (A), prolactin (B), oxytocin (C), and copeptin (D).

Results are expressed as mean \pm S.E.M. Statistical significance was determined by two-way ANOVA.

Published by Bioscientifica Ltd. 

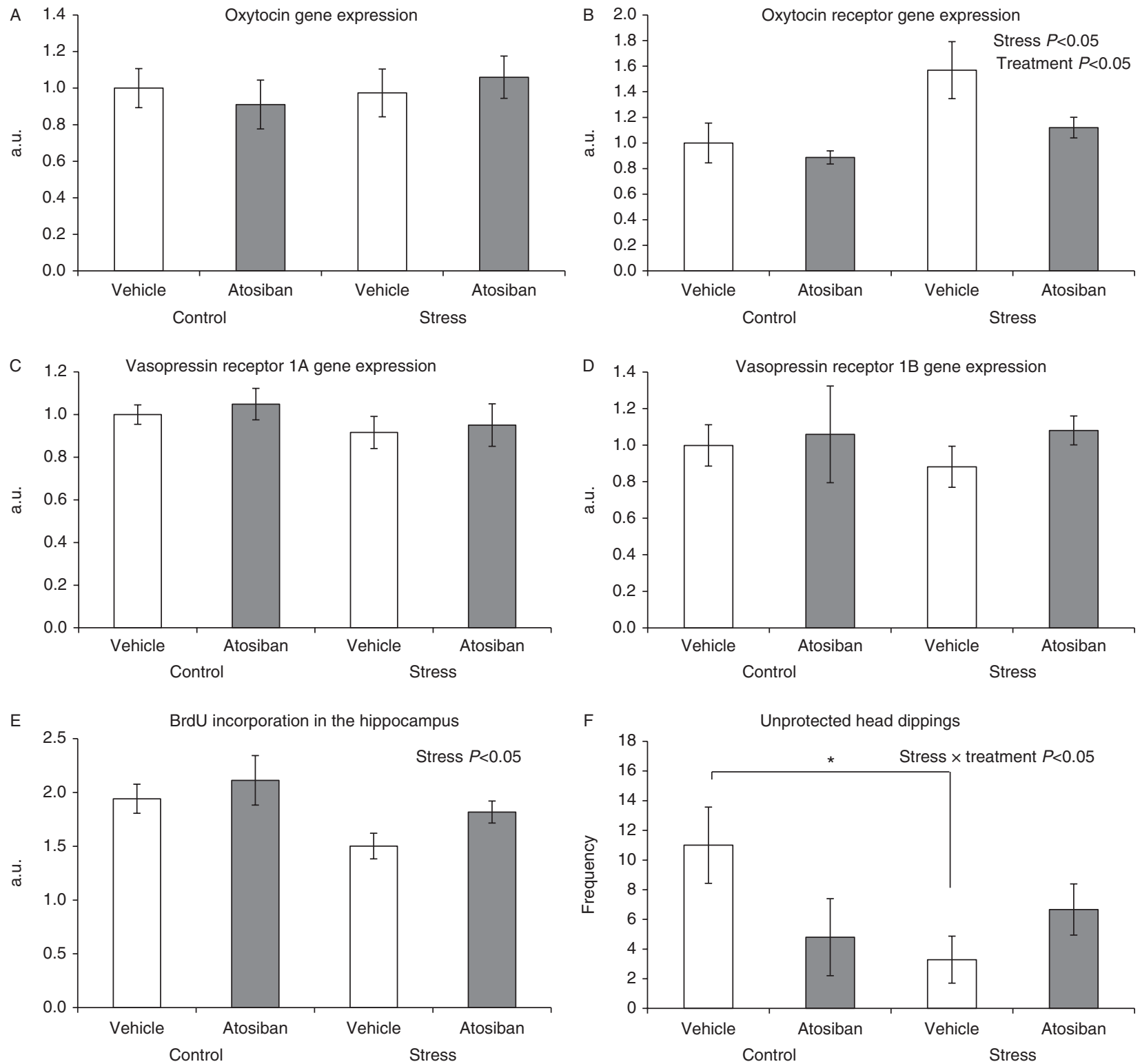

Figure 2

Effect of atosiban treatment and chronic stress exposure on (A) concentrations of oxytocin mRNA in the hypothalamus, (B) abundance of oxytocin receptor mRNA in the hypothalamus, (C) concentrations of vasopressin receptor $1 \mathrm{~A}$ mRNA in the hypothalamus, (D) concentrations of vasopressin receptor 1B

changed in response to stress exposure or treatment with atosiban.

Neither treatment with atosiban nor stress exposure altered daily water consumption. On the last day of the treatments, the water consumption in atosiban-treated rats was $26.9 \pm 2.34 \mathrm{ml}$ and that in vehicle-treated animals was $25.1 \pm 1.22 \mathrm{ml}$.

The incorporation of BrdU into DNA in the hippocampus was significantly less $\left(F_{(1,20)}=4.3945\right.$,

mRNA in the hypothalamus, (E) BrdU incorporation into the DNA in the hippocampus, and $(F)$ frequency of unprotected head dipping. Results are expressed as means \pm s.E.M. Statistical significance was determined by two-way ANOVA followed by the Fisher post hoc test. ${ }^{*} P<0.05$.

$P<0.05)$ in rats exposed to stress compared with that in controls. Treatment with atosiban had no effect on incorporation of BrdU into DNA in the hippocampus (Fig. 2E).

Anxiety-like behavior was evaluated by ethological (related to exploration and risk assessment behavior) as well as classical spatiotemporal (time spent in the openarm and open-arm entries) parameters in the elevated plus maze test. No significant changes were observed in the classical spatiotemporal parameters (results not shown).

Published by Bioscientifica Ltd. 
Statistical evaluation of the frequency of unprotected head dipping, an ethological parameter, showed a significant interaction $\left(F_{(1,25)}=5.3315, P<0.05\right)$ between the factors treatment and stress. Post hoc analysis showed that stressed animals treated with vehicle had a lower frequency of unprotected head dipping $(P<0.05)$ than control animals treated with vehicle (Fig. 2F). There were no effects of stress exposure on any of the plus maze test parameters in atosiban-treated rats.

\section{Discussion}

The present results indicate that in both control and stressed animals, treatment with atosiban resulted in decreased gene expression of oxytocin receptor in the hypothalamus and greater circulating concentrations of copeptin. The stress-induced decrease in cell proliferation in the hippocampus was not modified by atosiban treatment. Irrespective of atosiban treatment, repeated stress resulted in an increase in plasma oxytocin as well as in oxytocin receptor gene expression in the hypothalamus as measured $24 \mathrm{~h}$ following the last stress exposure.

Chronic treatment with atosiban resulted in significantly greater circulating concentrations of copeptin in both control and stressed animals. Copeptin, the C-terminal moiety of provasopressin, is cosecreted with vasopressin and its levels correlate well with circulating concentrations of vasopressin (Balanescu et al. 2011). It has been reported that atosiban blocks vasopressin 1 receptors (Pettibone et al. 1992). Thus, enhanced concentrations of copeptin indicate increased release of vasopressin in compensation for oxytocin and vasopressin $1 \mathrm{~A} / 1 \mathrm{~B}$ receptor blockade. It is unlikely that the rise in plasma copeptin concentrations, consistent with increased vasopressin release, resulted in major problems in water balance, as atosiban treatment did not affect water consumption. Concentrations of copeptin were unchanged $24 \mathrm{~h}$ after repeated stress exposure. Though copeptin (Katan \& Christ-Crain 2010) and vasopressin (Jezova et al. 1995) are considered to be stress hormones, a stress-induced elevation in vasopressin secretion was not expected. Previous studies using chronic or repeated stressors in rats showed unchanged or decreased vasopressin concentrations (Michajlovskij et al. 1988, Babic \& Jezova 2014).

Treatment with atosiban, particularly under non-stress conditions, led to an increase in plasma concentrations of prolactin. This is surprising because many results have indicated that oxytocin may act as a prolactin-releasing factor (Kennett \& McKee 2012). The treatment with a selective oxytocin antagonist, which does not cross the blood-brain barrier, infused intravenously via osmotic minipumps inhibited suckling-induced prolactin release (Kennett et al. 2009). However, the inhibitory action of a single injection of several oxytocin antagonists (Johnston $\&$ Negro-Vilar 1988) as well as of atosiban (Wilson 2007) was not supported by the results reported by other authors. The action of atosiban on prolactin release does not seem to be mediated by the blockade of vasopressin receptors, as prolactin concentrations were unchanged in vasopressin-deficient Brattleboro rats (Zelena et al. 2006).

Interestingly, chronic stress resulted in increased gene expression of oxytocin receptors in the hypothalamus induced by chronic stress together with downregulation of expression of these receptors by treatment with atosiban. To our knowledge, gene expression of oxytocin receptor in the hypothalamus under the conditions of chronic stress in rats or mice has not been studied thus far. Oxytocin receptors in the hypothalamus play an important role in energy homeostasis, including feeding behavior (Arletti et al. 1989) and thermoregulation (Kasahara et al. 2013). Oxytocin receptors are located in several hypothalamic nuclei and their roles in reproductive functions are underlined by changes in binding and/or gene expression during the estrous cycle and pregnancy (Bale et al. 1995, Bealer et al. 2006). Results from a recent study on prairie voles (Pournajafi-Nazarloo et al. 2013), an animal species with specific social behavior, revealed a decrease in oxytocin receptor mRNA concentration in the hypothalamus following chronic isolation. The finding of decreased mRNA concentration of oxytocin receptors in the hypothalamus in atosiban-treated animals appears to be the first evidence on the effect of atosiban on these neuropeptide receptors in the brain. We can speculate that the decrease in oxytocin receptor mRNA is the consequence of slowed degradation or internalization (Ismayilova et al. 2006). Similarly, we have recently observed a decrease in a metabotropic glutamate receptor, another G-proteincoupled receptor, gene expression in response to the treatment with its antagonist (Pokusa et al. 2014).

Gene expression of vasopressin $1 \mathrm{~A}$ and $1 \mathrm{~B}$ receptors was not altered by chronic stress and treatment with atosiban. Both vasopressin $1 \mathrm{~A}$ and $1 \mathrm{~B}$ receptors are widely distributed in the brain including the hypothalamus (Egashira et al. 2009). Vasopressin 1B receptors are also located in the pituitary and play a role in the control of HPA axis and stress-related behaviors. Results of previous studies had revealed no effect of stress exposure on vasopressin $1 \mathrm{~A}$ and/or $1 \mathrm{~B}$ receptor mRNA concentrations in the hypothalamus of rats (Schmidt et al. 2003) as well as in prairie voles (Pournajafi-Nazarloo et al. 2013). It should

Published by Bioscientifica Ltd. 
be noted that upregulation of vasopressin $1 \mathrm{~B}$ receptors in response to chronic stress at the pituitary level has been reported (Volpi et al. 2004).

The concentrations the of stress hormones ACTH and corticosterone were not influenced by atosiban treatment. As only a single dose of atosiban was used in the present studies, hormonal changes in response to higher doses of atosiban cannot be excluded.

Plasma ACTH, corticosterone, and prolactin were unchanged in rats exposed to the chronic stressor, which is not surprising because blood collection was not performed immediately after the cessation of the stress exposure. Interestingly, concentrations of oxytocin were found to be significantly increased even $24 \mathrm{~h}$ after the last stress exposure. Limited information is available on changes in oxytocin release in response to repeated or chronic stress stimuli. In our recent study, plasma oxytocin concentrations were elevated in response to immobilization stress even if repeated seven times. However, unlike the first stress exposure, oxytocin levels returned to normal $24 \mathrm{~h}$ following the 7 th exposure, indicating the development of an adaptation response (Danevova et al. 2013). The results of the present study reveal that exposure to this intensive stressor for 14 days is associated with prolongation of stress-induced elevation of plasma oxytocin.

The gene expression of oxytocin in the hypothalamus was unchanged. Relative to oxytocin gene expression in the brain, the present results indicating that there is no effect of stress exposure on oxytocin mRNA levels in the hypothalamus are consistent with the data provided by Flak et al. (2011), whose study also used a long-term stress. Results described in previous reports using shorter stress stimuli indicate that gene expression of oxytocin in hypothalamic magnocellular nuclei may increase, decrease, or remain unchanged (Jezova et al. 1995, Zheng et al. 2010, Babygirija et al. 2012).

Treatment with atosiban induced slightly equivocal changes in anxiety behavior. No significant changes were observed in classical plus maze parameters. For one of the ethological parameters, head dipping, stress exposure resulted in a decrease in reflection of its anxiogenic effect in vehicle-treated rats but not in atosiban-treated rats. However, the baseline level of anxiety behavior in atosiban-treated control rats was lower, though not significantly, than that in vehicle-treated rats. Hence, further reduction by stress exposure might not have been possible. It should be noted that, to our knowledge, no data are available on the permeability of the blood-brain barrier to atosiban. However, centrally mediated effects of peripherally injected atosiban have also been reported by other authors (Broadbear et al. 2011, Mak et al. 2012), indicating that the drug can reach at least certain regions of the brain. Several areas in the brain called circumventricular organs, including parts of the hypothalamus, are not protected by the blood-brain barrier (Bartanusz \& Jezová 1992). Supporting of the possibility that the action of atosiban could be exerted via a circumventricular organ is our previous detection of an oxytocin response to another peripherally injected neuropeptide mediated by a brain region unprotected by the blood-brain barrier (Bartanusz \& Jezová 1994).

A recognized negative consequence of chronic stress is impairment of brain plasticity (Mirescu \& Gould 2006, Babic et al. 2012) and this was also demonstrated in the present experiments. A significant decrease in cell proliferation, reflected by lower levels of BrdU incorporated into the DNA, was observed. However, BrdU incorporation into the DNA was unaffected by chronic treatment with atosiban. As atosiban is a blocker of oxytocin and vasopressin $1 \mathrm{~A} / 1 \mathrm{~B}$ receptors, these receptors do not seem to play a major role in the decrease in cell proliferation in the hippocampus induced by stress exposure.

In conclusion, treatment with the oxytocin and vasopressin $1 \mathrm{~A} / 1 \mathrm{~B}$ receptor antagonist atosiban results in an increase in copeptin release and a decrease in hypothalamic oxytocin receptor gene expression without altering the stress-induced decrease in cell proliferation. This study provides the first data, to our knowledge, revealing the effect of atosiban on gene expression of oxytocin receptors in the brain. Further studies are needed to confirm atosiban-induced changes in behavior. It may be suggested that oxytocin and vasopressin $1 \mathrm{~A} / 1 \mathrm{~B}$ receptors are not deeply involved in impairments of brain plasticity induced by stress exposure. Elevation in vasopressinergic tone by atosiban treatment, reflected by increased concentrations of plasma copeptin, should be considered with respect to its clinical use. We hope that the present results will encourage the performance of clinical trials aiming to explore possible atosiban modulation of hormone release and action.

Declaration of interest

The authors declare that there is no conflict of interest that could be perceived as prejudicing the impartiality of the research reported.

\section{Funding}

This study was supported by grants from Slovak Academy of SciencesNational Science Council of Taiwan Joint Research Projects Program (SAS-NSC JRP 2010/07), the Slovak Scientific Grant Agency (VEGA 2/0128/14) and the Slovak Research and Development Agency (APVV-0028-10).

Published by Bioscientifica Ltd 


\section{Acknowledgements}

The authors thank Ludmila Zilava and Jana Blaskova for their help during experiments and analyses. Antibody for corticosterone was kindly provided by Professor C Oliver (Marseille, France).

\section{References}

Arletti R, Benelli A \& Bertolini A 1989 Influence of oxytocin on feeding behaviour in the rat. Peptides 10 89-93. (doi:10.1016/01969781(89)90082-X)

Babic S \& Jezova D 2014 Effect of phenytoin treatment on cell proliferation in the hippocampus and the heart and related neuroendocrine changes under non-stress and stress conditions. Neurological Research $\mathbf{3 6}$ 112-117. (doi:10.1179/1743132813Y.0000000278)

Babic S, Ondrejcakova M, Bakos J, Racekova E \& Jezova D 2012 Cell proliferation in the hippocampus and in the heart is modified by exposure to repeated stress and treatment with memantine. Journal of Psychiatric Research 46 526-532. (doi:10.1016/j.jpsychires.2012.01.002)

Babygirija R, Bülbül M, Yoshimoto S, Ludwig K \& Takahashi T 2012 Central and peripheral release of oxytocin following chronic homotypic stress in rats. Autonomic Neuroscience 167 56-60. (doi:10.1016/j.autneu.2011. 12.005)

Balanescu S, Kopp P, Gaskill MB, Morgenthaler NG, Schindler C \& Rutishauser J 2011 Correlation of plasma copeptin and vasopressin concentrations in hypo-, iso-, and hyperosmolar states. Journal of Clinical Endocrinology and Metabolism 96 1046-1052. (doi:10.1210/jc. 2010-2499)

Bale TL, Dorsa DM \& Johnston CA 1995 Oxytocin receptor mRNA expression in the ventromedial hypothalamus during the estrous cycle. Journal of Neuroscience 15 5058-5064.

Bartanusz V \& Jezová D 1992 The role of some circumventricular organs in hormone action and secretion. Endocrine Regulations 26 3-9.

Bartanusz V \& Jezová D 1994 Angiotensin II induces reduced oxytocin but normal corticotropin release in rats with lesions of the subfornical organ. Fundamental \& Clinical Pharmacology 8 539-545. (doi:10.1111/ j.1472-8206.1994.tb00835.x)

Bealer SL, Lipschitz DL, Ramoz G \& Crowley WR 2006 Oxytocin receptor binding in the hypothalamus during gestation in rats. American Journal of Physiology. Regulatory, Integrative and Comparative Physiology 291 R53-R58. (doi:10.1152/ajpregu.00766.2005)

Bowen MT \& McGregor IS 2014 Oxytocin and vasopressin modulate the social response to threat: a preclinical study. International Journal of Neuropsychopharmacology 7 1-13. (doi:10.1017/S1461145714000388)

Broadbear JH, Tunstall B \& Beringer K 2011 Examining the role of oxytocin in the interoceptive effects of 3,4-methylenedioxymethamphetamine (MDMA, 'ecstasy') using a drug discrimination paradigm in the rat. Addiction Biology 16 202-214. (doi:10.1111/j.1369-1600.2010.00267.x)

Broadbear JH, Kabel D, Tracy L \& Mak P 2014 Oxytocinergic regulation of endogenous as well as drug-induced mood. Pharmacology, Biochemistry, and Behavior 119 61-71. (doi:10.1016/j.pbb.2013.07.002)

Danevova V, Kvetnansky R \& Jezova D 2013 Kinetics of oxytocin response to repeated restraint stress and/or chronic cold exposure. Hormone and Metabolic Research 45 845-848. (doi:10.1055/s-0033-1348265)

Devidze N, Mong JA, Jasnow AM, Kow LM \& Pfaff DW 2005 Sex and estrogenic effects on coexpression of mRNAs in single ventromedial hypothalamic neurons. PNAS 102 14446-14451. (doi:10.1073/pnas. 0507144102)

Duncko R, Kiss A, Skultetyova I, Rusnak M \& Jezova D 2001 Corticotropinreleasing hormone mRNA levels in response to chronic mild stress rise in male but not in female rats while tyrosine hydroxylase mRNA levels decrease in both sexes. Psychoneuroendocrinology 26 77-89. (doi:10. 1016/S0306-4530(00)00040-8)

Egashira N, Mishima K, Iwasaki K, Oishi R \& Fujiwara M 2009 New topics in vasopressin receptors and approach to novel drugs: role of the vasopressin receptor in psychological and cognitive functions. Journal of Pharmacological Sciences 109 44-49. (doi:10.1254/ jphs.08R14FM)

Engstrøm T, Bratholm P, Christensen NJ \& Vilhardt H 2000 Effect of oxytocin receptor blockade on rat myometrial responsiveness to prostaglandin $\mathrm{F}_{2 \alpha}$. Biology of Reproduction 63 1443-1449. (doi:10.1095/ biolreprod63.5.1443)

Flak JN, Jankord R, Solomon MB, Krause EG \& Herman JP 2011 Opposing effects of chronic stress and weight restriction on cardiovascular, neuroendocrine and metabolic function. Physiology \& Behavior 104 228-234. (doi:10.1016/j.physbeh.2011.03.002)

Goodwin TM, Paul R, Silver H, Spellacy W, Parsons M, Chez R, Hayashi R, Valenzuela G, Creasy GW \& Merriman R 1994 The effect of the oxytocin antagonist atosiban on preterm uterine activity in the human. American Journal of Obstetrics and Gynecology 170 474-478. (doi:10.1016/S0002-9378(94)70214-4)

Hemmerle AM, Herman JP \& Seroogy KB 2012 Stress, depression and Parkinson's disease. Experimental Neurology 233 79-86. (doi:10.1016/ j.expneurol.2011.09.035)

Hlavacova N \& Jezova D 2008 Chronic treatment with the mineralocorticoid hormone aldosterone results in increased anxiety-like behavior. Hormones and Behavior 54 90-97. (doi:10.1016/j.yhbeh.2008.02.004)

Husslein P, Roura LC, Dudenhausen J, Helmer H, Frydman R, Rizzo N, Schneider D \& TREASURE study group 2006 Clinical practice evaluation of atosiban in preterm labour management in six European countries. British Journal of Obstetrics and Gynaecology 115 674-675. (doi:10.1046/j.1471-0528.2003.00041.x-i1)

Ismayilova N, Verkhratsky A \& Dascombe MJ 2006 Changes in mGlu5 receptor expression in the basal ganglia of reserpinised rats. European Journal of Pharmacology 545 134-141. (doi:10.1016/j.ejphar. 2006.06.076)

Izakova L \& Jezova D 2013 Aldosterone - a new biological marker or another option in treatment of depression? Psychiatrie 1 13-18.

Jezova D \& Hlavacova N 2008 Endocrine factors in stress and psychiatric disorders: focus on anxiety and salivary steroids. Annals of the New York Academy of Sciences 1148 495-503. (doi:10.1196/annals.1410.050)

Jezova D, Guillaume V, Juránková E, Carayon P \& Oliver C 1994 Studies on the physiological role of ANF in ACTH regulation. Endocrine Regulations 28 163-169.

Jezova D, Skultetyova I, Tokarev DI, Bakos P \& Vigas M 1995 Vasopressin and oxytocin in stress. Annals of the New York Academy of Sciences $\mathbf{7 7 1}$ 192-203. (doi:10.1111/j.1749-6632.1995.tb44681.x)

Jezova D, Ochedalski T, Kiss A \& Aguilera G 1998 Brain angiotensin II modulates sympathoadrenal and hypothalamic pituitary adrenocortical activation during stress. Journal of Neuroendocrinology 10 67-72. (doi:10.1046/j.1365-2826.1998.00182.x)

Johnston CA \& Negro-Vilar A 1988 Role of oxytocin on prolactin secretion during proestrus and in different physiological or pharmacological paradigms. Endocrinology 122 341-350. (doi:10.1210/ endo-122-1-341)

Kasahara Y, Sato K, Takayanagi Y, Mizukami H, Ozawa K, Hidema S, So KH, Kawada T, Inoue N, Ikeda I et al. 2013 Oxytocin receptor in the hypothalamus is sufficient to rescue normal thermoregulatory function in male oxytocin receptor knockout mice. Endocrinology 154 4305-4315. (doi:10.1210/en.2012-2206)

Katan M \& Christ-Crain M 2010 The stress hormone copeptin: a new prognostic biomarker in acute illness. Swiss Medical Weekly 140 w13101. (doi:10.4414/smw.2010.13101)

Kennett JE \& McKee DT 2012 Oxytocin: an emerging regulator of prolactin secretion in the female rat. Journal of Neuroendocrinology 24 403-412. (doi:10.1111/j.1365-2826.2011.02263.x)

Kennett JE, Poletini MO, Fitch CA \& Freeman ME 2009 Antagonism of oxytocin prevents suckling- and estradiol-induced, but not progesterone-induced, secretion of prolactin. Endocrinology 150 2292-2299. (doi:10.1210/en.2008-1611) 
Livak KJ \& Schmittgen TD 2001 Analysis of relative gene expression data using real-time quantitative PCR and the $2^{-\Delta \Delta \mathrm{C}_{\mathrm{T}}}$ method. Methods $\mathbf{2 5}$ 402-408. (doi:10.1006/meth.2001.1262)

Mak P, Broussard C, Vacy K \& Broadbear JH 2012 Modulation of anxiety behavior in the elevated plus maze using peptidic oxytocin and vasopressin receptor ligands in the rat. Journal of Psychopharmacology 26 532-542. (doi:10.1177/0269881111416687)

McEwen BS 2012 The ever-changing brain: cellular and molecular mechanisms for the effects of stressful experiences. Developmental Neurobiology 72 878-890. (doi:10.1002/dneu.20968)

Michajlovskij N, Lichardus B, Kvetnanský R \& Ponec J 1988 Effect of acute and repeated immobilization stress on food and water intake, urine output and vasopressin changes in rats. Endocrinologia Experimentalis 22 $143-157$.

Mirescu C \& Gould E 2006 Stress and adult neurogenesis. Hippocampus 16 233-238. (doi:10.1002/hipo.20155)

Neumann ID 2007 Stimuli and consequences of dendritic release of oxytocin within the brain. Biochemical Society Transactions $\mathbf{3 5}$ 1252-1257. (doi:10.1042/BST0351252)

Pettibone DJ, Kishel MT, Woyden CJ, Clineschmidt BV, Bock MG, Freidinger RM, Veber DF \& Williams PD 1992 Radioligand binding studies reveal marked species differences in the vasopressin $V_{1}$ receptor of rat, rhesus and human tissues. Life Sciences $\mathbf{5 0} 1953-1958$. (doi:10.1016/0024-3205(92)90524-S)

Pokusa M, Prokopova B, Hlavacova N, Makatsori A \& Jezova D 2014 Effect of blockade of mGluR5 on stress hormone release and its gene expression in the adrenal gland. Canadian Journal of Physiology and Pharmacology 92 686-692. (doi:10.1139/cjpp-2014-0030)
Pournajafi-Nazarloo H, Kenkel W, Mohsenpour SR, Sanzenbacher L, Saadat H, Partoo L, Yee J, Azizi F \& Carter CS 2013 Exposure to chronic isolation modulates receptors mRNAs for oxytocin and vasopressin in the hypothalamus and heart. Peptides 43 20-26. (doi:10.1016/j.peptides.2013.02.007)

Schmidt ED, Aguilera G, Binnekade R \& Tilders FJ 2003 Single administration of interleukin-1 increased corticotropin releasing hormone and corticotropin releasing hormone-receptor mRNA in the hypothalamic paraventricular nucleus which paralleled long-lasting (weeks) sensitization to emotional stressors. Neuroscience 116 275-283. (doi:10.1016/S0306-4522(02)00555-9)

Usta IM, Khalil A \& Nassar AH 2011 Oxytocin antagonists for the management of preterm birth: a review. American Journal of Perinatology 28 449-460. (doi:10.1055/s-0030-1270111)

Volpi S, Rabadán-Diehl C \& Aguilera G 2004 Regulation of vasopressin V1b receptors and stress adaptation. Annals of the New York Academy of Sciences 1018 293-301. (doi:10.1196/annals.1296.035)

Wilson JH 2007 Social buffering in rats as measured by prolactin: a potential role for oxytocin. Journal of Psychiatry, Psychology and Mental Health 1 1-10.

Zelena D, Mergl Z \& Makara GB 2006 The role of vasopressin in diabetes mellitus-induced hypothalamo-pituitary-adrenal axis activation: studies in Brattleboro rats. Brain Research Bulletin 69 48-56. (doi:10.1016/j.brainresbull.2005.10.009)

Zheng J, Babygirija R, Bülbül M, Cerjak D, Ludwig K \& Takahashi T 2010 Hypothalamic oxytocin mediates adaptation mechanism against chronic stress in rats. American Journal of Physiology. Gastrointestinal and Liver Physiology 299 G946-G953. (doi:10.1152/ajpgi.00483.2009)

Received in final form 25 December 2014

Accepted 20 January 2015

Accepted Preprint published online 21 January 2015
(C) 2015 Society for Endocrinology Printed in Great Britain 